\title{
Journal lists in social sciences and the spectrum of quality standards
}

\author{
Raf Guns ${ }^{1}$ and Marek Hołowiecki ${ }^{2}$ \\ ${ }^{1}$ raf.guns@uantwerpen.be
}

Centre for R\&D Monitoring (ECOOM), Faculty of Social Sciences, University of Antwerp, Antwerp, Belgium

https://orcid.org/0000-0003-3129-0330

2 mh@amu.edu.pl

Scholarly Communication Research Group, Adam Mickiewicz University in Poznań, Poznań, Poland

https://orcid.org/0000-0001-8217-2815

Chapter accepted for publication in Engels, T.C.E. \& Kulczycki, E. (2021). Handbook on Research Assessment in the Social Sciences. Edward Elgar Publishing, ISBN 9781800372542.

\begin{abstract}
The social sciences involve multiple literatures, including journals with a more international and those with a more local orientation. Quality standards in research assessment have largely been borrowed from STEM fields and generally favour internationally oriented journals with high international visibility and scientific impact, to the detriment of other quality dimensions, such as relevance to local communities and researchers or openness of research.

In journal lists, this complex spectrum of quality standards is simplified into a onedimensional arrangement. We provide a typology to characterize journal lists and discuss the usage of journal lists in research assessment, arguing that their values and criteria deserve careful scrutiny and can be studied through systematic comparison.
\end{abstract}

\section{Keywords}

Journal lists; internationalization; peer review; questionable journals; quality standards

\section{Introduction: journals in the social sciences}

This chapter reviews the role of journal lists in research assessment for the social sciences, analyzing the main dimensions that affect the inclusion and ranking of journals on such lists. We argue that journal lists are popular because they simplify the complex spectrum of journal quality standards to a one-dimensional list. Our aim is to provide a framework by which journal lists can be characterized, understood and compared. 
Journal articles are the most widely used publication type in the social sciences, although there are substantial differences between disciplines and countries (Kulczycki et al., 2018). Hicks (2004) argued that international and national journals constitute two different literatures of the social sciences, in addition to books and non-scholarly literature. In other words, a part of the social science journal literature is globally oriented (Shah, 2020), while another part is locally oriented (Mkandawire, 1997). Both parts are relevant and neededindeed, social science research has been characterized as 'glocal,' i.e. global knowledge is used to solve local problems (Leshner, 2008). The spectrum of social sciences is very broad and ranges from, e.g., the differences between law and policies in African countries to social problems of megacities in Asia or America, or psychological challenges connected with the education of people living in unusual subsistence conditions. These examples illustrate how research carried out using globally accepted methods may have a mostly local impact.

The first journal literature discerned by Hicks (2004) consists of journals with a large international audience (Buela-Casal et al., 2006). Authors and citations of these journals also tend to be international (Wormell, 1998). Many of them are published by large commercial publishing houses (Larivière et al., 2015) and indexed in large international databases like Web of Science (WoS) or Scopus. It has been observed that these databases contain an overrepresentation of English-language journals (Archambault et al., 2006; Mongeon \& PaulHus, 2016).

The second journal literature consists of local journals, sometimes called national, domestic, "small", "emerging", or "peripheral" journals (Bocanegra-Valle, 2019). The audience of local journals tends to be smaller, which has a negative effect on research visibility as reflected in, e.g., citation counts (Kulczycki et al., 2019). Typically, most or all articles in a local journal are written in a local language. Editorial board, reviewers and authors tend to come from the same country or region (Dyachenko, 2014). Their impact on global science and associated international visibility are limited. Many of these journals have never been internationally evaluated. For instance, Kulczycki et al. (2019) argue that there is virtually no internationalization of Polish journals from the social sciences and humanities (SSH).

The two groups of journals serve a different purpose in the scholarly communication system of the social sciences. High-quality local journals play an important role in the local science system. López Piñeiro and Hicks (2015) found that Spanish sociologists communicate about different topics in local journals compared to international ones. It is possible, yet rare, for a local journal to transfer to the international group (Salager-Meyer, 2014).

The phenomenon of brain drain - flow of talent from poorer to wealthier nations - is wellknown (Wolfle, 1966). Similarly, local journals are facing the problem of publication drain (Salager-Meyer, 2015), where even young scholars often prefer to submit their best papers to English-language journals with a high impact factor. This issue is related to the incentive systems in many countries. For instance, Žic Fuchs (2014) concluded that Spain is facing a mass migration of the best articles to foreign languages, as well as increasing neglect of Spanish journals and Spanish language, due to changes in the national assessment system. Similarly, Haddow (chapter 27) mentions a concern in Australia that journal ranking can lead researchers to orient "away from more local concerns."

It should be clear from the discussion above that language is a central element to the internationality of a journal. Nowadays international research is dominated by English (Ashcroft et al., 2002), although other languages such as Arabic or French also function as a lingua franca sometimes (Sivertsen, 2018a). The dominance of English is reinforced by the fact that major citation indexes mainly index English-language journals and require English 
translations of titles and abstracts for indexation of non-English articles (Bocanegra-Valle, 2019). Kulczycki et al. (2020) recommended a greater balance between the demands of international excellence and the local relevance of research. Their research shows that $40 \%$ of authors from seven European countries who published at least 3 articles in years 2013-2015 wrote them in at least two languages. Less than $40 \%$ of the most productive scholars, who published 10 or more articles, did so in one language. The authors conclude that multilingual publishing keeps locally relevant research alive.

The remainder of the chapter is structured as follows. Section 2 reviews the different quality dimensions of journals, with a focus on readership and impact, peer review, and business practices. In section 2.4, we discuss how questionable journals subvert the pay-to-publish open access model, and how this affects peer review and impact. Section 3 focuses on journal lists: after introducing a general typology of journal lists (3.1), we describe a few national lists (3.2) and discuss current issues relating to the use of journal lists in research assessment (3.3). Finally, section 3.4 explains how the values and criteria of journal lists can be studied through comparison of lists. Section 4 contains the conclusions. The appendix provides an overview of the main lists discussed in the chapter.

\section{Spectrum of quality standards: dimensions of quality}

Journal quality is a multidimensional construct. Haustein (2012) distinguished between five dimensions, several of which are discussed in other chapters:

1. Journal output (size, publication types), see chapter 16 by Sivertsen;

2. Journal content (topics, scope), see chapters 3 by Bonaccorsi and 8 by Eykens;

3. Journal perception (readership and usage) can be described through the lens of altmetrics (cf. chapter 13 by Ebrahimzadeh, Alperin and Haustein) and is further discussed below;

4. Journal citations, see below;

5. Journal management (peer review, business model) encompasses aspects of open access (chapter 18 by Pölönen and Laakso) and open science (chapter 7 by Laakso), as well as peer review (chapter 5 by Seeber).

In this section, we discuss journal perception and citations (global and local impact), and journal management (peer review and business practices). We conclude the section outlining how 'questionable' or 'predatory' publishing is mainly related to these dimensions.

\subsection{Global and local readership and impact}

The dichotomy between local and international journals is a simplification of a more complex reality (Tijssen et al., 2006). Journals can be more locally or more internationally oriented in terms of multiple aspects, like their readership, citation rate, authors, publisher, language, and thematic scope.

Locally oriented research can be difficult to publish outside the borders of a given country (Tijssen et al., 2006) and hence often fails to reach international readership. However, scholarly journals that serve the local community may be highly visible and impactful in the local context; as such, these journals often publish research of great societal relevance.

In general, internationally oriented journals tend to be more visible in international indexes and score better on citation-based indicators like the journal impact factor (JIF). While the JIF in particular has often been criticized, it is still very common to delineate so-called top journals on the basis of the JIF. This is problematic for several reasons. First, the JIF as such 
has some inherent problems, such as the mismatch between denominator and numerator (e.g., Vanclay, 2011). Second, it puts locally relevant journals, which rarely have a JIF to begin with, at a serious disadvantage. In the SSH in particular, WoS indexation is limited to a minority of journals. Third, an overreliance on the JIF to determine which journals are 'toptier' may persist the misuse of this indicator for, e.g., evaluation of individual researchers.

In contrast, countries such as Denmark, Finland and Norway rely on disciplinary expert panels using qualitative criteria for selection and level assignment of journals. Kulczycki et al. (2021) find that journal lists in these countries leave "more room for journals in the social sciences and humanities and for locally relevant journals in general." While the rankings from these countries are also informed by — and hence correlate with-JIFs, they exhibit more variability in terms of JIF percentile and publisher country, especially in the SSH.

\subsection{Peer review}

One of the most important tasks of the journal is performing quality control of submitted manuscripts, through organizing peer review (see Seeber, chapter 5). While peer review itself is carried out by other researchers, organization of peer review involves both the publisher and one or more editors, who are also researchers. Organization of peer review refers to various aspects like setting up and maintenance of editorial systems, appointment of editorial assistants, and appointing and following up on referees. Some journals also carry out other forms of quality control, like plagiarism checking, statistical review, and copy-editing.

Peer review is one of the main criteria by which it is decided whether or not a journal should be taken into account in assessment and funding procedures, as well as which journals to include in many journal lists. While some lists only stipulate peer review as a requirement without further explanation, others specify in more detail the process or content of peer review. For instance, journals can only be included on the VABB-SHW journal list if they "apply a demonstrable peer-review process by scholars who are experts in the (sub)field to which the publication belongs" and "peer review should be done by an editorial board, a permanent reading committee, external referees, or by a combination of these" (Pölönen et al., 2020, p. 4), while Finnish regulations also address the contents of the review, which should assess "the completeness of the material and the management of the theoretical framework, the reliability of how the research has been carried out and its accuracy, and the originality of the results and their novelty in relation to previous research, as characteristic of the field of science" (Pölönen et al., 2020, p. 5). Most lists don’t distinguish between different forms of peer review, such as single-blind, double-blind or open identities.

\subsection{Business practices: closed and open access}

In the traditional 'closed access' model, the journal receives the copyright on the submitted paper, enabling the journal's publisher to sell subscriptions to research institutions or individual subscribers. Only subscribers can access the journal's contents, either in print or online. Open Access (OA) publications, on the other hand are freely and openly available online.

There are various forms of OA (cf. chapter 18 by Pölönen and Laakso), some of which are organized at the journal level. In the Gold $O A$ model, articles are made immediately and openly available in an OA journal. This can be financed by Article Processing Charges (APCs) paid by the author, or through other means. Gold OA without APCs is sometimes also referred to as Diamond OA (or Platinum OA). Hybrid OA refers to the situation where the author pays APCs to have the article be made openly available in a subscription journal. 
The major closed access publishers have also embraced the Hybrid and Gold OA models, and found ways to monetize these (Van Noorden, 2013). An influential list of (Gold and Diamond) OA journals is the Directory of Open Access Journals (DOAJ, https://doaj.org), which only indexes peer-reviewed journals that adhere to a set of quality standards.

\subsection{Questionable journals and related aspects}

The pay-to-publish model as present in APC-based Gold OA - and, to a lesser extent, the Hybrid OA model - introduces a dynamic that is not present in the traditional pay-to-read model or other OA models: it becomes far more interesting commercially to accept and publish many papers, since each published paper directly translates to publisher income. This has led to the advent of very large multidisciplinary Gold OA journals like 'mega-journals' (Spezi et al., 2017). Taken to its most extreme, this logic seems to imply that the most lucrative Gold OA journal simply accepts and publishes all submissions. There are, however, good reasons why the vast majority of Gold OA journals don't use such a business model. First, there is a reason of strategy or reactivity (Siler, 2020): this would be devastating to the reputation of the journal and its publisher, thereby reducing the number of submissions and longer-term revenue. Second, this presupposes that every journal is run by purely commercial logic. This is generally not the case, among other things because the editorial board of the journal consists of academics.

Some research assessment systems take publication numbers into account with little attention to the quality of the publication or publication channel. Hence, it should not come as a surprise that some journals have emerged that do accept and publish (nearly) everything. These are most commonly referred to as "predatory" publishers and journals (Beall, 2012). Following some recent studies (Eykens et al., 2019; Frandsen, 2019; Nelhans \& Bodin, 2020), we will refer to these as questionable publishers and journals, in recognition of the fact that it is hard to adequately distinguish bad-faith actors from low-quality ones. Typically, questionable journals exhibit problems relating to one or more of the following areas:

- Integrity: does the journal or publisher pretend to be something they are not? This includes issues like fake ISSNs, pretending to be non-profit when that's not the case, and causing confusion with a legitimate (high-profile) journal.

- Peer review: does the journal or publisher have an adequate peer review system and editorial board? Bohannon (2013) found that some journals accept obviously nonsensical publications. Some of these journals even introduced a non-existing person to the editorial team (Sorokowski et al., 2017).

- Fees: does the journal or publisher communicate clearly and correctly about any APCs or other fees?

- Access and copyright: does the journal or publisher have adequate (open) access and copyright policies and are these enacted in practice?

- Business practices: does the journal or publisher conduct its business appropriately and honestly? This includes the occurrence of misleading information on their websites, like a false country of publishing or metrics with similar names to the most prestigious metrics.

The above list is based on the criteria of Cabells International (Toutloff, 2019), which in addition also distinguish criteria relating to publication practices, and indexing and metrics. Taken together, these problems may lead to waste of funds and resources, poor quality research being given a false aura of reliability, and/or good quality research being available for a limited time or not at all. 
A recent proposal defines questionable journals as "entities that prioritize self-interest at the expense of scholarship and are characterized by false or misleading information, deviation from best editorial and publication practices, a lack of transparency, and/or the use of aggressive and indiscriminate solicitation practices" (Grudniewicz et al., 2019). This definition omits any reference to peer review, because it was deemed "impossible to assess." Indeed, many questionable journals purport to carry out peer review, although that is not necessarily the case. Bagues et al. (2019) carried out a survey among Italian researchers who had published in a journal on Beall's list of predatory journals (see 3.1). For 30\% of all journals, at least one respondent reported that they received no referee report or only comments related to editing. For an additional 6\%, at least one respondent reported noticing something else that seemed odd. These results suggest that a fair number of questionable journals do organize some form of peer review (see also Severin et al., 2020), but the reviews are not necessarily actively used.

Citation analysis also suggests that publications in questionable journals need not be of low quality. Several studies have found that some questionable journals publish articles that are cited in respected venues (Bagues et al., 2019; Frandsen, 2017), although the majority has little scientific impact (Björk et al., 2020). Articles in questionable journals are cited in Scopus-indexed journals mostly by people geographically located in the same region, especially South Asia and Africa (Frandsen, 2017).

\section{Journal lists}

Lists of scholarly journals have existed since at least the $19^{\text {th }}$ century, while the first journal ranking was produced in 1926 (Pölönen et al., 2021). Nowadays, their use in funding, evaluation and planning of research is widespread. After discussing types of journal lists and some examples of national lists, we focus on their use in research assessment and finally discuss how comparing lists may help to bring ambiguities (e.g., between reliable and questionable journals, or between peer-reviewed and non-peer-reviewed journals) to the surface.

\subsection{Typology}

Journal lists can be characterized according to multiple dimensions. The following typology is mostly based on Pölönen et al. (2021).

Geographic scope. Geographic scope can refer to usage-is the list used in an international, national, or local context? - as well as contents of the list. Note that locally and nationally used lists may contain international or foreign journals.

Selectivity. How selective is the list, i.e. how many and which quality criteria are used, and how rigorously are they applied? Criteria can relate to any dimension of quality (cf. 2.1), although some dimensions - such as quality control or metrics - are more commonly applied than others. Many of the national lists reviewed by Pölönen et al. (2021) treat peer review as the main criterion, usually in addition to some more technical requirements (e.g., ISSN). Lists without selectivity like Ulrich's or ISSN.org, are generally not used in evaluation settings.

Differentiation. Many lists are not only selective vis-à-vis inclusion, but also apply quality criteria to differentiate between included journals. This may range from ratings at two or more levels to full-fledged rankings, where there are (in principle) as many different levels as journals on the list. The original ERIH list used differentiation at three levels (A, B, C), whereas the current ERIH PLUS list has abandoned differentiation (Lavik \& Sivertsen, 
2016). Most often, differentiation is based on expert judgment and/or bibliometric indicators, but other criteria are possible. For instance, the DOAJ awards the DOAJ Seal to journals "that demonstrate best practice in open access publishing."

Field coverage. Does the list cover all fields or a specific selection? For lists that cover multiple fields, a key issue is how to ensure that each field is properly represented. This is more difficult than it seems. Articles in the social sciences are, for instance, scattered over more and smaller journals compared to STEM fields and, hence, one needs to include more journals from the social sciences if one wants to achieve a similar degree of coverage.

Journal reliability. Most journal lists are 'positive' in that they aim to include only reliable and legitimate journals. However, some lists are 'negative': journals on such lists are questionable and should be actively avoided. Positive and negative lists have also been referred to as whitelists and blacklists in the literature. Beall's list is probably the most wellknown example of a negative list. Jeffrey Beall's work has drawn a lot of attention to the issue of 'predatory' journals, both from a policy and from a research point of view. At the same time, several researchers and OA advocates have argued that the problem is overblown by Beall as well as some for-profit publishers (Olijhoek \& Tennant, 2018), the 'predatory' moniker is problematic (Eriksson \& Helgesson, 2018), and Beall's interpretation in particular lacks due process or clear criteria, and is marred by a strong aversion towards OA as well as a negative attitude towards less economically prosperous regions (Berger \& Cirasella, 2015; Crawford, 2014). Beall's lists were taken offline in 2017, but some others persist or have appeared since (see Nelhans \& Bodin, 2020 for an overview). With the exception of Cabells Predatory Reports, these other lists have not been studied much. Hence, their characteristics and contents are not well understood.

\subsection{Use of lists in research assessment}

The main reason for the popularity of journal lists in research assessment is simplicity: the broad spectrum of quality standards (cf. 2.1) is simplified to a one-dimensional journal list, the general assumption being that the list's maintainers have made conscious decisions to include (and rank) certain journals and exclude others based on criteria like reliability, peer review, internationality, and impact (e.g., Testa, 2009). Compared to the complexity of multiple criteria, lists are easy and therefore attractive to use.

Performance-based research funding systems (PRFS) in many countries rely on journal lists as part of the procedure. Likewise, the use of journal lists is common in evaluation procedures at the national or institutional level. Following the comprehensive overview of national scholarly publication channel lists by Pölönen et al. (2021), some national lists are described below as examples of how journal lists inform and support research assessment and funding distribution.

In China several journal lists are in use for different purposes. Among the most important is the CAS Journal List, prepared by the Chinese Academy of Sciences (CAS). It serves as a tool to evaluate the influence of international journals, and is used in some institutions for evaluation at the individual level (Huang et al., 2021).

The Italian National Agency for the Evaluation of Universities and Research Institutes (ANVUR) is an evaluation agency that prepares a classification of "scientific" and "Class A" journals. ANVUR also determines minimum standards of research production for candidates for research positions and supervises internal administrative evaluation systems of universities and research bodies. 
The Spanish agency Fundación Española para la Ciencia y Tecnología (FECYT) have prepared a list of SSH journals published in Spain. Journals are evaluated according to formal and impact criteria, and can receive a FECYT Quality seal (Sello FECYT). The list serves, among other uses, as a supportive tool for Spanish research evaluation agencies (CNEAI and ANECA).

In Australia, the ERA Journal List is an integral part of the Excellence in Research for Australia (ERA) evaluation process, whose main task is the identification of excellence in research. This is done by comparing Australia's university research outcome against international benchmarks.

Various European countries use systems modelled after or inspired by the Norwegian model (Sivertsen, 2018b). Denmark, Finland and Norway each maintain national lists of publication channels assigned to different levels for use in the PRFS. In Flanders (Belgium), the PRFS is based on two data sources: WoS and VABB-SHW, a local database for SSH publications. Each data source corresponds to a separate journal list; while the VABB-SHW journal list is not differentiated, the WoS-based journal list is divided into twenty segments with an associated weight.

As a final example, Poland works with the list of Polish Journal Ranking (PJR) created by the Ministry of Science and Higher Education since 1999. The list is used as a part of national PRFS for funding scientific institutions, in promotion procedures and as a base for monetary reward systems.

The above examples illustrate that journal lists have been widely used for many years in different settings, most often as a supportive tool for research evaluation. At the same time, the use of journal lists is often considered problematic. First, it is debatable to what extent a journal's rating or ranking is an adequate indicator of an article's or author's value (Seglen, 1994; Zhang et al., 2017). Second, many lists have been criticized for not properly upholding the criteria they purport to be based on (e.g., Dony et al., 2020; Patwardhan et al., 2018; Taşkin et al., 2015) or for being biased. For example, the original ERIH list assigned local and non-English journals to category $\mathrm{C}$, which was often interpreted as lower quality (Pölönen et al., 2021). Third, many lists are used in inappropriate or at least unintended ways, such as the use of ERIH's three categories as quality levels in Poland (Kulczycki et al., 2015). This problem is related to the fact that many lists don't make their purposes and criteria sufficiently explicit. Fourth, the simplicity of journal lists carries an inherent danger that all research will be standardized to the same one-dimensional international norms, to the detriment of locally relevant research (López Piñeiro \& Hicks, 2015; Pontille \& Torny, 2016).

Furthermore, the controversies surrounding usage of journal lists in research evaluation have led to debates on two more specific issues. The first major point of discussion is whether metric- or expert-based criteria are most appropriate. Use of bibliometric indicators to select, rate and/or rank journals is controversial for the $\mathrm{SSH}$, since citations may have different meanings and these fields are poorly covered in citation indexes (Ferrara \& Bonaccorsi, 2016). In spite of these criticisms, new metric-based approaches are still being developed (e.g., De Filippo et al., 2020). Expert-based approaches, on their part, have been criticized for subjectivity and lack of representativeness or transparency (Pontille \& Torny, 2010). A possible solution is the use of metrics-informed expert assessment, as practiced in, e.g., the Nordic countries.

The second issue is the question if and to what extent journal hierarchies (i.e., differentiated ratings or rankings) should be used. The majority of journal hierarchies have been created by 
policy makers for evaluation purposes. An example is the Polish journal ranking system, in which points are assigned to scholarly journals (Kulczycki, 2017). Since 2017 external reviewers (experts) have been involved in the process of assigning points to journals. These points are understood as a proxy of quality and aggregated on institutional level used as part of research funding mechanism in Poland. Very often international journals published by large publishing houses are ranked higher than local journals that publish locally relevant articles. Science policy can shape the publication patterns in a country. However, the policy has to be carefully implemented and explicitly stated to result in expected effects (Korytkowski \& Kulczycki, 2019).

External databases like Web of Science or Scopus are known to influence journal hierarchies, even in the case of local lists. This is especially controversial if indicators like the JIF play a role. In some fields, researchers have started ranking journals themselves, either based on quantitative indicators or on survey-based approaches. Especially in the latter case, a journal has a better chance to be on top of the hierarchy if it is older and well-established, or if it is published by a well-known learned society (DeJong \& St. George, 2018).

\subsection{Comparison of lists}

It is most likely impossible to formulate one catch-all definition of 'questionable', 'legitimate', or 'top-tier' journals, since formulating such a definition implies making value statements on which dimensions are most important. The results of earlier studies indicate that there is a continuum: some journals are widely accepted as prototypical examples of either high-quality or questionable outlets, but in between those extremes, there is a 'grey zone' where different actors reach different conclusions regarding a journal's peer review status (Pölönen et al., 2020) or 'predatory' nature (Siler, 2020).

Such ambiguities can be studied and operationalized by comparing journal lists. The comparison can involve various aspects, including criteria, included journals (overlap and differences), and rating or ranking of journals. Since each list contains one perspective on a multifaceted reality, it is instructive to use or compare multiple journal lists, both for those who maintain a list and for research evaluators.

- Maintainers of a journal list can use the results to improve their own list, e.g. to ensure adequate representation of multiple fields or languages.

- By relying on more than one list, research evaluators can avoid depending too much on one particular viewpoint and can assess to what extent there is convergent validity on what constitutes a 'good' or 'bad' journal in a specific field or context.

Hicks and Wang (2011) compare the SSH journal lists of Scopus, Web of Science, the ERA, ERIH, and the Norwegian list, relying on Ulrich's as a comprehensive baseline. None of the studied lists cover more than $40 \%$ of the SSH journals in Ulrich's. The authors consider this "disappointing," although this finding is partially explained by the implicit and explicit goals of each list. For instance, WoS and Scopus avoid lowly cited journals, and the Norwegian list mainly focuses on journals used by Norwegian scholars. In other words, one should always take into account the reasons why a journal is included or excluded.

Hicks and Wang (2011) also consider the overlap between Scopus, WoS, ERA, ERIH, and the Norwegian list. They find that "the lists and databases overlap a great deal, but each contains journals not indexed by anyone else except Ulrich's" (p. 289), although overlap is greater for English-language and WoS-indexed journals. The main factors explaining consensus on a journal's scholarliness were its language, country of origin, publisher size, 
and age. Hence, comparison of journal lists across country and language boundaries may also be beneficial to ensure that non-English social science journals from smaller publishers are adequately recognized elsewhere.

In a comparison of the Finnish and Flemish journal lists, Pölönen et al. (2020) showed that there is substantial ambiguity regarding the question which journals practice peer review. Ambiguity concerning peer review status also manifested in differences between 'top-down' classification by centralized panels and 'bottom-up' classification by authors, and between co-publications reported differently by different authors' institutions. Overall, they found that the peer review status of 8 to $9.5 \%$ of publication channels is ambiguous. The grey zone of peer review is typically higher for the humanities than for the social sciences. Ambiguity seems to arise especially when a channel is also used to communicate with professional and general audience: it is more common - around 20\% — in case of book publications (versus journal articles) and in case of publications in minority languages.

Overlap between lists, or lack thereof, may also be indicative of the grey zone between legitimate and questionable journals, in two different ways. First, there is substantial overlap between lists of questionable journals and sources like Scopus or WoS's Emerging Sources Citation Index (e.g., Macháček \& Srholec, 2021). This apparent paradox may be due to differences in criteria: while the former focus more on editorial practices, the latter mostly focus on formal criteria (e.g., availability of abstract and affiliation data) and on the reception of research (e.g., citations). Second, it is quite remarkable that there is fairly little commonality between different lists of questionable journals. Nelhans and Bodin (2020) compared Cabell's blacklist, the Iran MHME list, and the list of journals removed from DOAJ for suspected editorial misconduct. They conclude that "very few publications could be found in all three lists" (p. 518).

Even if two differentiated lists both include the same journal, they may rank it very differently. This applies to metric-based rankings as well as expert-based rankings. As for metric-based rankings, there is a sizable literature on the comparison of bibliometric indicators and data sources, and the rankings derived from them. The general consensus is that, although most journal citation indicators are rather strongly correlated, they can lead to substantial differences in ranking (Mingers \& Yang, 2017). Expert-based rankings can deviate even more, especially when criteria such as relevance to a national context are used. While deviations between expert-based rankings are not necessarily problematic, it is recommended to take the ranking in other relevant lists into account. An example of this kind of data exchange can be found in the Nordic countries, where the ranking in other lists as well as bibliometric indicators are provided to the panels that decide on a journal's level.

\section{Conclusion}

\subsection{Chapter summary}

The social sciences involve two different journal literatures - both internationally oriented journals and journals with a more local outlook. Traditional quality standards in research assessment have largely been borrowed from STEM fields and generally favour internationally oriented journals with high visibility and scientific impact. However, journal quality is a multidimensional construct (Haustein, 2012). In recent years, there has been a growing awareness of other quality dimensions, such as openness of research or relevance to local communities and researchers. This evolution has important ramifications for research assessment, and also impacts the use of journal lists: there is a growing realization that local 
journals may be crucially important to the social sciences. Consequently, international lists are not always the most appropriate tools, since they mainly reflect quality standards relating to international visibility and impact, to the detriment of other, potentially more relevant dimensions. Nowadays, many countries across the globe work with national journal listsoften alongside, or in addition to, international lists - for purposes of evaluation, assessment, and funding distribution.

Journal lists are not neutral instruments; the criteria by which they are compiled, reflect certain values. While it is recommended that those criteria and values are made explicit (Pölönen et al., 2021), this is not always the case. In addition, even if criteria are made explicit, they may not be systematically applied and/or ambiguities may arise. We have argued that through comparison of lists, issues like (ambiguity in) peer review, quality dimensions, and questionable publishing, can be further studied and understood.

\subsection{Implications for research assessment}

Journals are arguably the most important kind of publication channel in the social sciences. Consequently, journal articles play a major role in most forms of research assessment. This does not automatically imply that journal lists should be used. For instance, assessment methods that rely on expert review of a researcher's most important or relevant publications can work without journal lists. As the volume of publications to be taken into account grows and as the assessment takes place at higher levels of aggregation, such as research groups or institutes, the use of journal lists becomes more and more inevitable.

In cases where usage of a journal list is deemed appropriate, the evaluators should make a deliberate and well-considered choice, taking into account the list's guidelines and its type (cf. the typology in 3.1). The crucial task is to ensure that the journal list adequately represents the research that should be evaluated. Some aspects that are especially relevant for social science research include geographic and linguistic scope (i.e., representation of both international and local journals) as well as field coverage. It may happen that none of the available lists tick all the boxes; possible solutions include the instalment of a new list or the combination of several existing lists. Ideally, the decision of which list(s) to use in research assessment is taken together with the entities that are being evaluated.

Finally, we recommend critically evaluating — and, if needed, revising or updating - the choice of journal list in research assessment. This is important because both lists and the research under assessment are prone to changes. As we have argued in this chapter, the comparison of journal lists may help to clarify which list is more appropriate in a specific context. 


\section{References}

Archambault, É., Vignola-Gagné, É., Côté, G., Larivière, V., \& Gingras, Y. (2006). Benchmarking scientific output in the social sciences and humanities: The limits of existing databases. Scientometrics, 68(3), 329-342. https://doi.org/10.1007/s11192$006-0115-\mathrm{z}$

Ashcroft, B., Griffiths, G., \& Tiffin, H. (2002). The empire writes back: Theory and practice in post-colonial literatures (2nd ed.). Routledge.

Bagues, M., Sylos-Labini, M., \& Zinovyeva, N. (2019). A walk on the wild side: 'Predatory' journals and information asymmetries in scientific evaluations. Research Policy, 48(2), 462-477. https://doi.org/10.1016/j.respol.2018.04.013

Beall, J. (2012). Predatory publishers are corrupting open access. Nature, 489(7415), 179. https://doi.org/10.1038/489179a

Berger, M., \& Cirasella, J. (2015). Beyond Beall's list: Better understanding predatory publishers. College \& Research Libraries News, 76(3), 132-135.

https://doi.org/10.5860/crln.76.3.9277

Björk, B. C., Kanto-Karvonen, S., \& Harviainen, J. T. (2020). How frequently are articles in predatory open access journals cited. Publications, 8(2), Article 17. https://doi.org/10.3390/publications8020017

Bocanegra-Valle, A. (2019). Building a reputation in global scientific communication: A SWOT analysis of Spanish humanities journals. Canadian Journal of Sociology, 44(1), 39-66. https://doi.org/10.29173/cjs28935

Bohannon, J. (2013). Who's afraid of peer review? Science, 342(6154), 60-65. https://doi.org/10.1126/science.342.6154.60

Buela-Casal, G., Perakakis, P., Taylor, M., \& Checa, P. (2006). Measuring internationality: Reflections and perspectives on academic journals. Scientometrics, 67(1), 45-65. https://doi.org/10.1556/Scient.67.2006.1.4

Crawford, W. (2014). Ethics and access 1: The sad case of Jeffrey Beall. Cites \& Insights, $14(4), 1-14$ 
De Filippo, D., Aleixandre-Benavent, R., \& Sanz-Casado, E. (2020). Toward a classification of Spanish scholarly journals in social sciences and humanities considering their impact and visibility. Scientometrics. 125(2), 1709-1732. https://doi.org/10.1007/s11192-020-03665-5

DeJong, C., \& St. George, S. (2018). Measuring journal prestige in criminal justice and criminology. Journal of Criminal Justice Education, 29(2), 290-309. https://doi.org/10.1080/10511253.2017.1398344

Dony, C., Raskinet, M., Renaville, F., Simon, S., \& Thirion, P. (2020). How reliable and useful is Cabell's blacklist? A data-driven analysis. LIBER Quarterly, 30(1), 1-38. https://doi.org/10.18352/lq.10339

Dyachenko, E. L. (2014). Internationalization of academic journals: Is there still a gap between social and natural sciences? Scientometrics, 101(1), 241-255. https://doi.org/10.1007/s11192-014-1357-9

Eriksson, S., \& Helgesson, G. (2018). Time to stop talking about 'predatory journals.' Learned Publishing, 31(2), 181-183. https://doi.org/10.1002/leap.1135

Eykens, J., Guns, R., Rahman, A. I. M. J., \& Engels, T. C. E. (2019). Identifying publications in questionable journals in the context of performance-based research funding. PLOS ONE, 14(11), Article e0224541. https://doi.org/10.1371/journal.pone.0224541

Ferrara, A., \& Bonaccorsi, A. (2016). How robust is journal rating in humanities and social sciences? Evidence from a large-scale, multi-method exercise. Research Evaluation, 25(3), 279-291. https://doi.org/10.1093/reseval/rvv048

Frandsen, T. F. (2017). Are predatory journals undermining the credibility of science? A bibliometric analysis of citers. Scientometrics, 113(3), 1513-1528. https://doi.org/10.1007/s11192-017-2520-x

Frandsen, T. F. (2019). Why do researchers decide to publish in questionable journals? A review of the literature. Learned Publishing, 32(1), 57-62. https://doi.org/10.1002/leap.1214

Grudniewicz, A., Moher, D., Cobey, K. D., Bryson, G. L., Cukier, S., Allen, K., Ardern, C., Balcom, L., Barros, T., Berger, M., Ciro, J. B., Cugusi, L., Donaldson, M. R., Egger, 
M., Graham, I. D., Hodgkinson, M., Khan, K. M., Mabizela, M., Manca, A. ... Lalu, M. M. (2019). Predatory journals: No definition, no defence. Nature, 576(7786), 210212. https://doi.org/10.1038/d41586-019-03759-y

Haustein, S. (2012). Multidimensional journal evaluation: Analyzing scientific periodicals beyond the impact factor. Walter de Gruyter.

Hicks, D. (2004). The four literatures of social science. In H. F. Moed, W. Glänzel, \& U. Schmoch (Eds.), Handbook of quantitative science and technology research: The use of publication and patent statistics in studies of S\&T systems (pp. 473-496). Springer.

Hicks, D., \& Wang, J. (2011). Coverage and overlap of the new social sciences and humanities journal lists. Journal of the American Society for Information Science and Technology, 62(2), 284-294. https://doi.org/10.1002/asi.21458

Huang, Y., Li, R., Zhang, L., \& Sivertsen, G. (2021). A comprehensive analysis of the journal evaluation system in China. Quantitative Science Studies, 2(1), 300-326. https://doi.org/10.1162/qss_a_00103

Korytkowski, P., \& Kulczycki, E. (2019). Examining how country-level science policy shapes publication patterns: The case of Poland. Scientometrics, 119(3), 1519-1543. https://doi.org/10.1007/s11192-019-03092-1

Kulczycki, E. (2017). Assessing publications through a bibliometric indicator: The case of comprehensive evaluation of scientific units in Poland. Research Evaluation, 26(1), 41-52. https://doi.org/10.1093/reseval/rvw023

Kulczycki, E., Engels, T. C. E., Pölönen, J., Bruun, K., Dušková, M., Guns, R., Nowotniak, R., Petr, M., Sivertsen, G., Starčič, A. I., \& Zuccala, A. A. (2018). Publication patterns in the social sciences and humanities: Evidence from eight European countries. Scientometrics, 116(1), 463-486. https://doi.org/10.1007/s11192-018-27110

Kulczycki, E., Guns, R., Pölönen, J., Engels, T. C. E., Rozkosz, E. A., Zuccala, A. A., Bruun, K., Eskola, O., Starčič, A. I., Petr, M., \& Sivertsen, G. (2020). Multilingual publishing in the social sciences and humanities: A seven-country European study. Journal of the Association for Information Science and Technology, 71(11), 1371-1385. https://doi.org/10.1002/asi.24336 
Kulczycki, E., Huang, Y., Zuccala, A. A., Engels, T. C. E., Ferrara, A., Guns, R., Pölönen, J., Sivertsen, G., Taşkın, Z., \& Zhang, L.(2021). National policies for top-tier journals in Europe and China go beyond the Impact Factor. Under review.

Kulczycki, E., Rozkosz, E. A., \& Drabek, A. (2015). Publikacje polskich badaczy w czasopismach z list ERIH w kontekście ewaluacji jednostek naukowych. Kultura $i$ Edukacja, 107(1), 149-172. https://doi.org/10.15804/kie.2015.01.08

Kulczycki, E., Rozkosz, E. A., \& Drabek, A. (2019). Internationalization of Polish journals in the social sciences and humanities: Transformative role of the research evaluation system. Canadian Journal of Sociology, 44(1), 9-38. https://doi.org/10.29173/cjs28794

Larivière, V., Haustein, S., \& Mongeon, P. (2015). The oligopoly of academic publishers in the digital era. PLOS ONE, 10(6), Article e 0127502. https://doi.org/10.1371/journal.pone.0127502

Lavik, G. A. V., \& Sivertsen, G. (2016). ERIH PLUS - Making the SSH visible, searchable and available. Procedia Computer Science, 106, 61-65. https://doi.org/10.1016/j.procs.2017.03.035

Leshner, A. I. (2008). “Glocal” science advocacy. Science, 319(5865), 877-877. https://doi.org/10.1126/science.1155656

López Piñeiro, C., \& Hicks, D. (2015). Reception of Spanish sociology by domestic and foreign audiences differs and has consequences for evaluation. Research Evaluation, 24(1), 78-89. https://doi.org/10.1093/reseval/rvu030

Macháček, V., \& Srholec, M. (2021). Predatory publishing in Scopus: Evidence on crosscountry differences. Scientometrics, 126(3), 1897-1921. https://doi.org/10.1007/s11192-020-03852-4

Mingers, J., \& Yang, L. (2017). Evaluating journal quality: A review of journal citation indicators and ranking in business and management. European Journal of Operational Research, 257(1), 323-337. https://doi.org/10.1016/j.ejor.2016.07.058

Mkandawire, T. (1997). The social sciences in Africa: Breaking local barriers and negotiating international presence. The Bashorun M. K. O. Abiola distinguished lecture presented 
to the 1996 African sudies association annual meeting. African Studies Review, 40(2), 15-36. https://doi.org/10.2307/525155

Mongeon, P., \& Paul-Hus, A. (2016). The journal coverage of Web of Science and Scopus: A comparative analysis. Scientometrics, 106(1), 213-228. https://doi.org/10.1007/s11192-015-1765-5

Nelhans, G., \& Bodin, T. (2020). Methodological considerations for identifying questionable publishing in a national context: The case of Swedish Higher Education Institutions. Quantitative Science Studies, 1(2), 505-524. https://doi.org/10.1162/qss_a_00033

Olijhoek, T., \& Tennant, J. (2018). The "problem" of predatory publishing remains a relatively small one and should not be allowed to defame open access. LSE Impact of Social Sciences. http://blogs.lse.ac.uk/impactofsocialsciences/2018/09/25/theproblem-of-predatory-publishing-remains-a-relatively-small-one-and-should-not-beallowed-to-defame-open-access/

Patwardhan, B., Nagarkar, S., Gadre, S. R., Lakhotia, S. C., Katoch, V. M., \& Moher, D. (2018). A critical analysis of the "UGC-approved list of journals." Current Science, 114(6), 1299-1303. https://doi.org/10.18520/cs/v114/i06/1299-1303

Pölönen, J., Engels, T. C. E., \& Guns, R. (2020). Ambiguity in identification of peerreviewed publications in the Finnish and Flemish performance-based research funding systems. Science and Public Policy, 47(1), 1-15. https://doi.org/10.1093/scipol/scz041

Pölönen, J., Guns, R., Kulczycki, E., Sivertsen, G., \& Engels, T. C. E. (2021). National lists of scholarly publication channels: An overview and recommendations for their construction and maintenance. Journal of Data and Information Science, 6(1), 50-86. https://doi.org/10.2478/jdis-2021-0004

Pontille, D., \& Torny, D. (2010). The controversial policies of journal ratings: Evaluating social sciences and humanities. Research Evaluation, 19(5), 347-360. https://doi.org/10.3152/095820210x12809191250889

Pontille, D., \& Torny, D. (2016). Excellence internationale, pertinence linguistique: Les classements de revues en SHS. In S. Borg, M. Cheggour, N. Desrochers, L. Gajo, V. Larivière, \& M. Vlad (Eds.), L'Université en contexte plurilingue dans la dynamique numérique (pp. 221-227). Éditions des archives contemporaines. 
Salager-Meyer, F. (2014). Writing and publishing in peripheral scholarly journals: How to enhance the global influence of multilingual scholars? Journal of English for Academic Purposes, 13, 78-82. https://doi.org/10.1016/j.jeap.2013.11.003

Salager-Meyer, F. (2015). Peripheral scholarly journals: From locality to globality. Ibérica, Revista de la Asociación Europea de Lenguas para Fines Específicos, 30, 15-36. https://doaj.org/article/a15afce6544644b3a986e72c869ff6d3

Seglen, P. O. (1994). Causal relationship between article citedness and journal impact. Journal of the American Society for Information Science, 45(1), 1-11. https://doi.org/10.1002/(SICI)1097-4571(199401)45:1\%3C1::AIDASI1\%3E3.0.CO;2-Y

Severin, A., Strinzel, M., Egger, M., Domingo, M., \& Barros, T. (2020). Who reviews for predatory journals? A study on reviewer characteristics. bioRxiv. https://doi.org/10.1101/2020.03.09.983155

Shah, H. (2020). Global problems need social science. Nature, 577(7790), Article 295. https://doi.org/10.1038/d41586-020-00064-X

Siler, K. (2020). Demarcating spectrums of predatory publishing: Economic and institutional sources of academic legitimacy. Journal of the Association for Information Science and Technology, 71(11), 1386-1401. https://doi.org/10.1002/asi.24339

Sivertsen, G. (2018a). Balanced multilingualism in research. In Actes de colloque international L'évaluation de la recherche scientifique: Enjeux, méthodes et instruments (pp. 88-102). Conseil supérieur de l'éducation de la formation et de la recherche scientifique http://colloque.csefrs.ma/wp-content/uploads/2019/01/Actesdu-colloque-2017-6-11-2018.pdf

Sivertsen, G. (2018b). The Norwegian model in Norway. Journal of Data and Information Science, 3(4), 3-19. https://doi.org/10.2478/jdis-2018-0017

Sorokowski, P., Kulczycki, E., Sorokowska, A., \& Pisanski, K. (2017). Predatory journals recruit fake editor. Nature, 543(7646), 481-483. https://doi.org/10.1038/543481a

Spezi, V., Wakeling, S., Pinfield, S., Creaser, C., Fry, J., \& Willett, P. (2017). Open-access mega-journals: The future of scholarly communication or academic dumping ground? 
A review. Journal of Documentation, 73(2), 263-283. https://doi.org/10.1108/JD-062016-0082

Taşkın, Z., Doğan, G., Akça, S., Şencan, İ., \& Akbulut, M. (2015). Does Scopus put its own journal selection criteria into practice? In Proceedings of the 15th International Conference on Scientometrics and Informetrics, (pp. 1198-1199). Bogaziçi University Printhouse. https://www.issi-society.org/proceedings/issi_2015/1198.pdf

Testa, J. (2009). The Thomson Reuters journal selection process. Transnational Corporations Review, 1(4), 59-66. https://doi.org/10.1080/19186444.2009.11658213

Tijssen, R. J. W., Mouton, J., Van Leeuwen, T. N., \& Boshoff, N. (2006). How relevant are local scholarly journals in global science? A case study of South Africa. Research Evaluation, 15(3), 163-174. https://doi.org/10.3152/147154406781775904

Toutloff, L. (2019, March 20). Cabells Predatory Report criteria v 1.1. Cabells The Source. https://blog.cabells.com/2019/03/20/predatoryreport-criteria-v1-1/

Van Noorden, R. (2013). Open access: The true cost of science publishing. Nature, 495(7442), 426-429. https://doi.org/10.1038/495426a

Vanclay, J. K. (2011). Impact factor: Outdated artefact or stepping-stone to journal certification? Scientometrics, 92(2), 211-238. https://doi.org/10.1007/s11192-0110561-0

Wolfle, D. (1966). Brain drain. Science, 154(3752), 965. https://doi.org/10.1126/science.154.3752.965

Wormell, I. (1998). Informetric analysis of the international impact of scientific journals: How 'international' are the international journals? Journal of Documentation, 54(5), 584-605. https://doi.org/10.1108/EUM0000000007182

Zhang, L., Rousseau, R., \& Sivertsen, G. (2017). Science deserves to be judged by its contents, not by its wrapping: Revisiting Seglen's work on journal impact and research evaluation. PLOS ONE, 12(3), Article e0174205. https://doi.org/10.1371/journal.pone.0174205 
Žic Fuchs, M. (2014). The future of publications in the humanities. In P. Dávidházi (Ed.), New publication cultures in the humanities: Exploring the paradigm shift (pp. 147172). Amsterdam University Press. https://doi.org/10.2307/j.ctt12877w9.12 


\section{Appendix: Overview of lists discussed in the chapter}

\begin{tabular}{|c|c|c|c|}
\hline List & Type & Description & Website \\
\hline ISSN Portal & $\begin{array}{l}\text { Internatio } \\
\text { nal, not } \\
\text { selective }\end{array}$ & $\begin{array}{l}\text { The ISSN Register stores "key } \\
\text { identification information about print } \\
\text { and digital journals, magazines, }[\ldots] \\
\text { published in more than } 100 \text { countries." }\end{array}$ & $\begin{array}{l}\text { https://portal.issn.o } \\
\text { rg/ }\end{array}$ \\
\hline $\begin{array}{l}\text { Ulrich's } \\
\text { Periodicals } \\
\text { Directory }\end{array}$ & $\begin{array}{l}\text { Internatio } \\
\text { nal, not } \\
\text { selective }\end{array}$ & $\begin{array}{l}\text { This comprehensive source of print and } \\
\text { electronic serials data "features in-depth } \\
\text { coverage for more than } 300,000 \text { serials } \\
\text { from } 90,000 \text { publishers covering } 950 \\
\text { subject areas and } 200 \text { languages." }\end{array}$ & $\begin{array}{l}\text { https://about.proqu } \\
\text { est.com/products- } \\
\text { services/Ulrichswe } \\
\text { b.html }\end{array}$ \\
\hline $\begin{array}{l}\text { Directory of } \\
\text { Open Access } \\
\text { Journals } \\
\text { (DOAJ) }\end{array}$ & $\begin{array}{l}\text { Internatio } \\
\text { nal }\end{array}$ & $\begin{array}{l}\text { DOAJ focuses on OA journals from all } \\
\text { fields of science. Nowadays it contains } \\
\text { over } 15,000 \text { peer-reviewed OA journals. }\end{array}$ & https://doaj.org/ \\
\hline $\begin{array}{l}\text { Cabell's } \\
\text { Predatory } \\
\text { Reports }\end{array}$ & $\begin{array}{l}\text { Internatio } \\
\text { nal, } \\
\text { negative }\end{array}$ & $\begin{array}{l}\text { A database of "deceptive and predatory } \\
\text { academic journals" that contains } \\
\text { information about } 14,927 \text { questionable } \\
\text { journals from all disciplines. Previously } \\
\text { known as Cabell's Journal Blacklist. }\end{array}$ & $\begin{array}{l}\text { http://www2.cabell } \\
\text { s.com/about- } \\
\text { predatory }\end{array}$ \\
\hline $\begin{array}{l}\text { Beall's list of } \\
\text { potential } \\
\text { predatory } \\
\text { journals and } \\
\text { publishers }\end{array}$ & $\begin{array}{l}\text { Internatio } \\
\text { nal, } \\
\text { negative }\end{array}$ & $\begin{array}{l}\text { In addition to the list of predatory } \\
\text { publishers, Beall maintained a list of } \\
\text { "questionable, scholarly open-access } \\
\text { standalone journals." No longer updated } \\
\text { since January } 2017 \text {. }\end{array}$ & $\begin{array}{l}\text { https://beallslist.ne } \\
\text { t/ (a copy of } \\
\text { Beall's list of } \\
\text { predatory } \\
\text { publishers) }\end{array}$ \\
\hline ERIH PLUS & $\begin{array}{l}\text { Internatio } \\
\text { nal, SSH } \\
\text { only, } \\
\text { undifferen } \\
\text { tiated }\end{array}$ & $\begin{array}{l}\text { Index of peer-reviewed journals from } \\
\text { SSH, with focus on Europe. Its } \\
\text { predecessor ERIH only covered the } \\
\text { Humanities and was differentiated into } \\
\text { three categories. }\end{array}$ & $\begin{array}{l}\text { https://dbh.nsd.uib. } \\
\text { no/publiseringskan } \\
\text { aler/erihplus/index }\end{array}$ \\
\hline $\begin{array}{l}\text { Excellence in } \\
\text { Research for } \\
\text { Australia } \\
\text { (ERA) }\end{array}$ & $\begin{array}{l}\text { National, } \\
\text { undifferen } \\
\text { tiated }\end{array}$ & $\begin{array}{l}\text { Australian list of journals used for } \\
\text { research evaluation }\end{array}$ & $\begin{array}{l}\text { https://www.arc.go } \\
\text { v.au/excellence- } \\
\text { research- } \\
\text { australia/era-2018- } \\
\text { journal-list }\end{array}$ \\
\hline $\begin{array}{l}\text { CAS Journal } \\
\text { list }\end{array}$ & $\begin{array}{l}\text { National, } \\
\text { includes } \\
\text { only } \\
\text { natural } \\
\text { science } \\
\text { journals }\end{array}$ & $\begin{array}{l}\text { Chinese list of journals used locally in } \\
\text { reward systems and promotion } \\
\text { procedures. }\end{array}$ & $\begin{array}{l}\text { http://www.fenqub } \\
\text { iao.com/ }\end{array}$ \\
\hline $\begin{array}{l}\text { VABB-SHW } \\
\text { journal list }\end{array}$ & $\begin{array}{l}\text { National, } \\
\text { SSH only, } \\
\text { undifferen } \\
\text { tated }\end{array}$ & $\begin{array}{l}\text { List of peer-reviewed journals published } \\
\text { in by Flemish SSH scholars }\end{array}$ & $\begin{array}{l}\text { https://www.ecoo } \\
\text { m.be/en/data- } \\
\text { collections/vabb- } \\
\text { shw }\end{array}$ \\
\hline
\end{tabular}




\begin{tabular}{|c|c|c|c|}
\hline $\begin{array}{l}\text { BFI journal } \\
\text { list }\end{array}$ & $\begin{array}{l}\text { National, } \\
\text { differentia } \\
\text { ted }\end{array}$ & $\begin{array}{l}\text { Danish list of peer-reviewed journals, } \\
\text { three quality levels }\end{array}$ & $\begin{array}{l}\text { https://ufm.dk/en/r } \\
\text { esearch-and- } \\
\text { innovation/statistic } \\
\text { s-and- } \\
\text { analyses/bibliomet } \\
\text { ric-research- } \\
\text { indicator/bfi-lists }\end{array}$ \\
\hline $\begin{array}{l}\text { Finnish } \\
\text { Publication } \\
\text { Forum }\end{array}$ & $\begin{array}{l}\text { National, } \\
\text { differentia } \\
\text { ted }\end{array}$ & $\begin{array}{l}\text { Finnish list of peer-reviewed journals, } \\
\text { four quality levels }\end{array}$ & $\begin{array}{l}\text { https://www.julkai } \\
\text { sufoorumi.fi/en }\end{array}$ \\
\hline $\begin{array}{l}\text { Norwegian } \\
\text { Register for } \\
\text { Scientific } \\
\text { Journals, } \\
\text { Series and } \\
\text { Publishers }\end{array}$ & $\begin{array}{l}\text { National, } \\
\text { differentia } \\
\text { ted }\end{array}$ & $\begin{array}{l}\text { Norwegian list of peer-reviewed } \\
\text { journals, three quality levels }\end{array}$ & $\begin{array}{l}\text { https://dbh.nsd.uib. } \\
\text { no/publiseringskan } \\
\text { aler/Forside.action } \\
\text { ?request_locale=en }\end{array}$ \\
\hline
\end{tabular}

